\title{
Climatic Controls on Stable Carbon and Nitrogen Isotope Compositions of Temperate Grasslands in Northern China
}

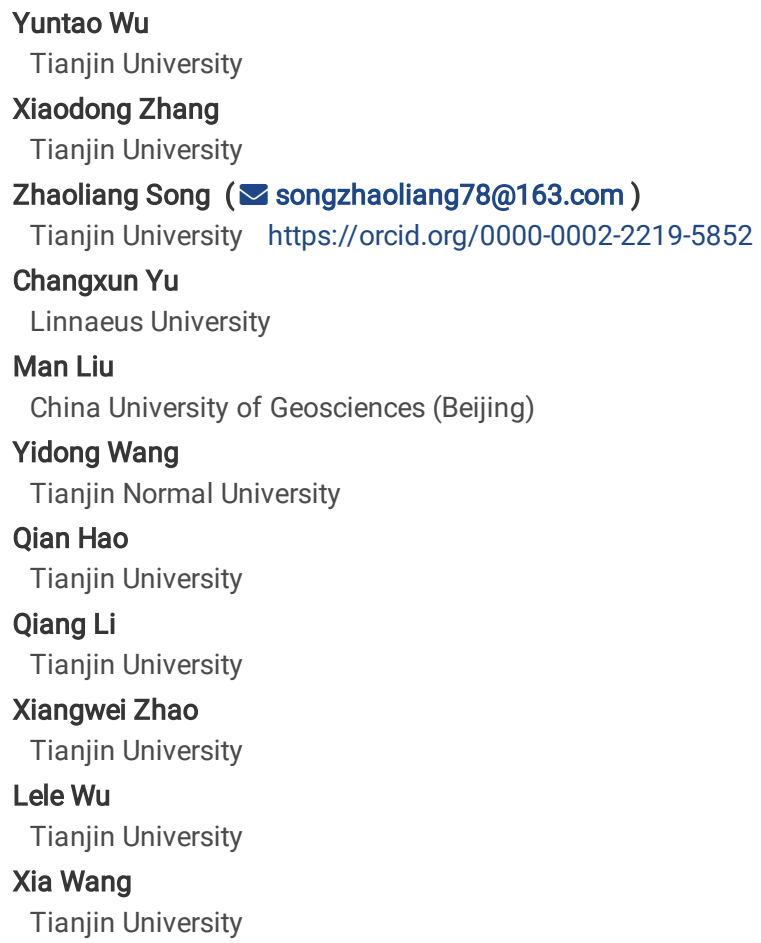

Research Article

Keywords: Carbon isotope, Nitrogen isotope, Northern grasslands, SOC turnover

Posted Date: January 3rd, 2022

DOI: https://doi.org/10.21203/rs.3.rs-1126749/v1

License: (c) (i) This work is licensed under a Creative Commons Attribution 4.0 International License. Read Full License 


\section{Abstract}

Aims The natural abundances of stable carbon $(C)$ and nitrogen $(N)$ isotopes $\left(\delta^{13} \mathrm{C}\right.$ and $\left.\delta^{15} \mathrm{~N}\right)$ are extensively used to indicate the $\mathrm{C}$ and $\mathrm{N}$ biogeochemical cycles at large spatial scales. However, the spatial patterns of $\delta^{13} \mathrm{C}$ and $\delta^{15} \mathrm{~N}$ in plant-soil system of grasslands in northern China and their main driving factors are still not well understood.

Methods We conducted sampling campaigns during 2016-2018 in grasslands of northern China and measured plant and soil $\delta^{13} \mathrm{C}$ and $\delta^{15} \mathrm{~N}$ compositions to determine effects soil physicochemical properties and climatic factors on spatial distribution of $\delta^{13} \mathrm{C}$ and $\delta^{15} \mathrm{~N}$.

Results Generally, plant and soil $\delta^{13} \mathrm{C}$ values increased with the decrease of mean annual precipitation (MAP). The interactions between mean annual temperature (MAT) and soil organic carbon have significant impact on soil $\delta^{13} \mathrm{C}$. However, plant and soil $\delta^{15} \mathrm{~N}$ decreased with the increase of MAT. Within all factors, the interactions between MAT and MAP on soil $\delta^{15} \mathrm{~N}$ were significant.

Conclusions Our results suggest that $\mathrm{C}$ cycling in grasslands of northern China is strongly mediated by plant community and MAT, because C4 species were more prevalent in arid regions. Meanwhile, $\mathrm{N}$ cycling is mainly directly regulated by MAT and plant community composition via its effect on the plant $\delta^{15} \mathrm{~N}$. All of these will provide scientific references for future research on the $\mathrm{C}$ and $\mathrm{N}$ biogeochemical cycles of temperate grassland ecosystems in northern China.

\section{Introduction}

Grasslands, comprising open grassland, grassy shrublands and savannas, cover nearly $40 \%$ of the world's land area and provide a wide range of ecosystem services to humans (O'Mara 2012; Bardgett et al. 2021). They store approximately one-third of the total carbon (C) in terrestrial ecosystems and most of the $\mathrm{C}$ is stored within $1 \mathrm{~m}$ soil layers, which contributes significantly to the mitigation of global climate change (Wang et al. 2016; Xu et al. 2015). In addition, grasslands also play an important role in the global nitrogen (N) biogeochemical cycle (Chen et al. 2021; Risch et al. 2019). Grasslands are vulnerable terrestrial ecosystems due to overexploitation (Liu et al. 2020). C and $\mathrm{N}$ cycles in global grassland ecosystems are sensitive to global climate change and land-use change, especially extreme precipitation and global warming in the temperate zone (Wang et al. 2016). However, it is difficult to explore the $\mathrm{C}$ and $\mathrm{N}$ dynamics by directly measuring the change of $\mathrm{C}$ and $\mathrm{N}$ stocks because of their relatively slow change processes. Recently, with the rapid development of stable isotope ratio mass spectrometry, stable $C\left(\delta^{13} \mathrm{C}\right)$ and $N\left(\delta^{15} \mathrm{~N}\right)$ isotope compositions, reflecting $\mathrm{C}$ and $\mathrm{N}$ transformation processes in plant-soil systems, have become an important tool to study the $\mathrm{C}$ and $\mathrm{N}$ biogeochemical cycles in terrestrial ecosystems (Dong et al. 2018; Han et al. 2020; Xia et al. 2021).

Nowadays, stable $\delta^{13} \mathrm{C}$ isotope has emerged as useful tool to assess the magnitude and distribution of plant productivity, water use efficiency and soil $\mathrm{C}$ turnover rate (Mcdowell et al. 2010; Wu et al. 2018). Previous studies have indicated that plant $\delta^{13} \mathrm{C}$ composition is mainly controlled by plant's photosynthetic pathway, and soil $\delta^{13} \mathrm{C}$ composition mainly depends on the plant-derived organic C and SOC decomposition (An and Li 2015; Dixon et al. 2010). Plant community composition has a distinct influence on the plant $\delta^{13} \mathrm{C}$ (Chen et al. 2021; Luo et al. 2018). For example, the plant community composition with more $\mathrm{C} 4$ species will lead to higher stable $\delta^{13} \mathrm{C}$ values (Wu et al. 2019). In addition, forbs with higher water use efficiency also have relatively higher $\delta^{13} \mathrm{C}$ values compared to graminoids and sedges (Liu et al. 2018). Besides, the soil stable $\delta^{13} \mathrm{C}$ composition has become an important integrative measure of soil organic carbon (SOC) input and output (Bird et al. 1996; Wang et al. 2017). Soil stable $\delta^{13} \mathrm{C}$ composition depends not only on that of plant residuals, but also on synthetic action of abiotic and biotic factors (e.g., SOC decomposition, microbial mobilization and immobilization) (Wu et al 2019; Yang et al. 2015). Besides, the stable $\delta^{13} \mathrm{C}$ composition can differ significantly among various layers within the same soil profiles (Brunn et al. 2014; Carvalhais et al. 2014; Wang et al. 2017). Up-to-date, studies in tropical, temperate and tundra regions have demonstrated that soil physicochemical properties (e.g., $\mathrm{pH}, \mathrm{C} / \mathrm{N}$ ratio and soil moisture) and climatic factors (e.g., mean annual temperature and mean annual precipitation) regulate biogeochemical processes in soil and influence interactions between soil and plants, and can shape the spatial and temporal distribution of stable $\delta^{13} \mathrm{C}$ composition in the terrestrial ecosystem (Nel et al. 2018; Yang et al. 2015).

Compared to the $\mathrm{C}$ cycle, the $\mathrm{N}$ cycle is more complex due to the various influencing factors along different environment gradients (Craine et al. 2015). Numerous studies have demonstrated that stable $\delta^{15} \mathrm{~N}$ values in terrestrial ecosystems are positively correlated with mean annual temperature (MAT) but negatively related to mean annual precipitation (MAP) (Craine et al. 2015; Nel et al. 2018). Besides, stable $\delta^{15} \mathrm{~N}$ composition is also influenced by soil C and $\mathrm{N}$ contents and other soil physicochemical properties (Craine et al. 2015; Yang et al. 2013). For example, ammonia $\left(\mathrm{NH}_{3}\right)$ volatilization will accelerate when soil pH is high, which leads to an abiotic gaseous $\mathrm{N}$ loss and higher soil $\delta^{15} \mathrm{~N}$ values (Booth et al. 2005; Chen et al. 2021; Yang et al. 2013). Generally, stable $\delta^{15} \mathrm{~N}$ signals the openness of $\mathrm{N}$ biogeochemical cycle in terrestrial ecosystems (Boeckx et al. 2005). The $\mathrm{N}$ input in terrestrial ecosystems by livestock manure, biological $\mathrm{N}$ fixation and $\mathrm{N}$ deposition could alter the stable $\delta^{15} \mathrm{~N}$ composition in plant-soil system (Fang et al. 2011). The stable $\delta^{15} \mathrm{~N}$ composition of plant also depends on the various preferences of species to the available $\mathrm{N}$ forms and the fractionation during plant mycorrhiza transfer process (Chen et al. 2021; Wu et al. 2019; Xu et al. 2011). The soil stable $\delta^{15} \mathrm{~N}$ is mainly controlled by plant $\mathrm{N}$ uptake and microbial mediated $\mathrm{N}$-cycling processes (Golluscio et al. 2009).

Being one of the most widely-distributed terrestrial ecosystems, grasslands play a crucial role in the global terrestrial biogeochemical cycles of $\mathrm{C}$ and $\mathrm{N}$ (Yan et al. 2017; Yao et al. 2018). Grasslands in China are mainly distributed in arid and semi-arid regions, covering an area of approximately $4 \times 10^{8}$ ha and accounting for $41.7 \%$ of the country's territory, and contain different grassland types adapted to various climatic conditions and altitudes. Previous studies have shown that the stable $\delta^{13} \mathrm{C}$ and $\delta^{15} \mathrm{~N}$ compositions of plant and soil are mainly controlled by climatic variables and soil characteristics (Wu et al. 2018) and increased our understanding of $\mathrm{C}$ and $\mathrm{N}$ cycles at both regional and global scales. However, there are few studies on the role of climatic factors in 
regulating the stable $\delta^{13} \mathrm{C}$ and $\delta^{15} \mathrm{~N}$ compositions in temperate grassland ecosystems. Therefore, this study focuses on the $\delta^{13} \mathrm{C}$ and $\delta^{15} \mathrm{~N}$ of plants and soils in grasslands of northern China. We aimed to explore the spatial patterns of $\delta^{13} \mathrm{C}$ and $\delta^{15} \mathrm{~N}$ in plant-soil system of grasslands in northern China and their driving factors. The results will provide scientific references for future research on the $\mathrm{C}$ and $\mathrm{N}$ biogeochemical cycles of grassland ecosystem.

\section{Materials And Methods}

\subsection{Study area}

This study was conducted in the Inner Mongolian Plateau along a precipitation gradient $\left(41.06^{\circ}-49.48^{\circ} \mathrm{N}, 114.26^{\circ}-120.94^{\circ} \mathrm{E}\right)$ in northern China (Figure 1$)$. The plateau is characterized by a dry and cold climate and belongs to the continental semi-arid grasslands of the Central Asian steppe ecosystem, with MAT ranging from -0.2 to $9{ }^{\circ} \mathrm{C}$, and MAP ranging from 152 to $502 \mathrm{~mm}$. Over $66 \%$ of the plateau is covered by temperate desert steppe (TDS), temperate typical steppe (TTS) and temperate meadow steppe (TMS). The three grassland types are distributed along the precipitation gradient across the plateau. Temperate meadow steppe is located at the wet end of the precipitation gradient, and the dominating species are Stipa baicalensis, Filifolium sibiricum, and Carex

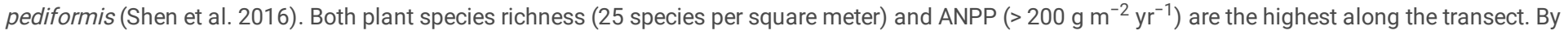
contrast, temperate desert steppe is distributed at the dry end of the precipitation gradient, and consists of Cleistogenes squarrosa, Agropyron mongolicum and $C$. duriuscula, which has the minimum ANPP $\left(<60 \mathrm{~g} \mathrm{~m}^{-2} \mathrm{yr}^{-1}\right)$ and plant species richness (3 species per square meter). In the middle of the precipitation gradient, temperate typical steppe is dominated by Stipa grandis, S. krylovii and Artemisia sacrorum, which has a medium ANPP and plant species richness. The growing season of vegetation is mainly from May to September, during which the precipitation accounts for about $80 \%$ of the whole year. Based on the Chinese soil classification system, the soil types in temperate meadow steppe, temperate typical steppe and temperate desert steppe are Chemozem, Kastanozems and Calcisols, respectively.

\subsection{Field sampling}

We conducted three consecutive sampling campaigns during the summer (from June to August) of 2016-2018, and sampled 255 biomass plots and soil profiles from 85 sites covering all major grassland types in northern China. To avoid human disturbance, all sampling sites were located about $1 \mathrm{~km}$ away from the major roads. At each site, a 30×30 m quadrat was randomly selected. Soil samples were collected from three pits at a depth of 0-10, 10-20, 20-40, and $40-60 \mathrm{~cm}$. Within each quadrat, aboveground parts of all plants in three $1 \times 1 \mathrm{~m}$ plots were harvested. All the plant samples were rinsed with pure water $(18.2 \mathrm{M} \Omega \mathrm{cm})$ to remove dust particles and then oven-dried for $60 \mathrm{~h}$ at $65^{\circ} \mathrm{C}$. Soil samples were naturally air-dried and then passed through $2 \mathrm{~mm}$ mesh sieve after removing big roots and rocks. Both the plant and soil samples were ground into a fine powder for determination of physicochemical properties and isotope values.

\subsection{Chemical and isotope measurement}

Soil pH was measured by immersing an electronic meter in a 1:2.5 mixture of the homogenized soil material and pure water, with a precision of \pm 0.5 (Han et al., 2020). Soil samples passed through a $2 \mathrm{~mm}$ sieve were used to determine soil particle sizes by Mastersizer 3000 (Malvern Instruments, Malvern,

England) and the error was less than $1 \%$. Soil samples were finely ground $(<149 \mu \mathrm{m})$, treated with $0.5 \mathrm{~mol} \mathrm{~L}^{-1} \mathrm{HCl}$ solution at room temperature for $24 \mathrm{~h}$ and then washed to neutrality, dried and ground for determining soil organic carbon (SOC) content. The values of SOC, soil total nitrogen (STN) and the C and N contents of plant were measured by an elemental analyzer (Elemetaranalysator vario Max CN, Germany), with a precision of $\leq 0.01 \%$. Quality assurance of methodologies was checked with a standard soil reference sample (GBW07405) and the precision was better than 5\%. Actual SOC contents in the original soil samples should be calibrated because the removal of inorganic C reduces sample mass (Liu et al., 2021).

The weight of soil and plant samples used for isotope analysis depends on the $\mathrm{C}$ and $\mathrm{N}$ contents of the samples. The ${ }^{13} \mathrm{C} /{ }^{12} \mathrm{C}$ and ${ }^{15} \mathrm{~N} /{ }^{14} \mathrm{~N}$ ratios were determined by a stable isotope ratio mass spectrometer (MAT-253 plus, USA) coupled to an elemental analyzer (Li et al. 2021; Wu et al. 2019; Yang et al. 2015). The results were normalized based on the measured values of standards (Vienna Pee Dee Belemnite standard for ${ }^{13} \mathrm{C} /{ }^{12} \mathrm{C}$, atmospheric $\mathrm{N}_{2}$ standard for ${ }^{15} \mathrm{~N} /{ }^{14} \mathrm{~N}$ ) and the $\delta^{13} \mathrm{C}$ and $\delta^{15} \mathrm{~N}$ values were calculated as follows:

$\delta^{13} \mathrm{C}(\%)=\left(R_{\text {sample }} / R_{\text {std }}-1\right) \times 10^{3}(1)$

$\delta^{15} \mathrm{~N}(\%)=\left(R_{\text {sample }} / R_{\text {std }}-1\right) \times 10^{3}(2)$

where $R_{\text {sample }}$ is the ratio of ${ }^{13} \mathrm{C} /{ }^{12} \mathrm{C}$ (or ${ }^{15} \mathrm{~N} /{ }^{14} \mathrm{~N}$ ) of the sample and $R_{\text {std }}$ is the ${ }^{13} \mathrm{C} /{ }^{12} \mathrm{C}$ of Vienna Pee Dee Belemnite standard or the ${ }^{15} \mathrm{~N} /{ }^{14} \mathrm{~N}$ of atmospheric $\mathrm{N}_{2}$ standard. The precision for the $\delta^{13} \mathrm{C}$ and $\delta^{15} \mathrm{~N}$ measurements is $0.1 \%$ and $0.2 \%$, respectively.

\subsection{Statistical analyses}

One-way ANOVA analysis with least significant difference (LSD) test was performed to determine the significance of $\delta^{13} \mathrm{C}$ and $\delta^{15} \mathrm{~N}$ values in different grassland types at the level of $p<0.05$. The correlations between the $\delta^{13} \mathrm{C}$ and $\delta^{15} \mathrm{~N}$ values and different climate factors and soil properties were determined by linear regression analysis. A general linear model (GLM) was used to evaluate the combined effects of climate factors (MAT and MAP), soil properties (pH, EC, Clay, SOC, STN and the $\mathrm{C} / \mathrm{N}$ ratio) and plant community composition on $\delta^{13} \mathrm{C}$ and $\delta^{15} \mathrm{~N}$ values in vegetation and surface soil (0-10 cm). Meanwhile, the structural equation model (SEM) was used to test direct and indirect effects of soil properties, climate factors and plant community composition on $\delta^{13} \mathrm{C}$ and $\delta^{15} \mathrm{~N}$ values in vegetation and surface soil. This statistical method can use a multiple regression approach to explain the interactions and nonlinearities. 


\section{Results}

\subsection{Soil physicochemical properties}

The grasslands of northern China displayed significant differences in soil physicochemical properties (Table 2). Soil pH in temperate meadow steppe was lower than that in temperate typical steppe and temperate desert steppe, and there was no significant difference among various soil layers of each grassland type. However, soil EC in temperate meadow steppe was significantly higher than that in temperate typical steppe and temperate desert steppe, especially in the surface soils $(0-10 \mathrm{~cm})$. SOC and TN contents showed similar distribution trends and decreased with soil depth in each grassland type. At the same time, the values of SOC and TN in temperate meadow steppe showed a decreasing trend along the precipitation gradient in the grasslands of northern China, and were highest in the temperate meadow steppe (Table 2). Meanwhile, the $\mathrm{C} / \mathrm{N}$ ratio showed the opposite trend and slightly increased with increasing precipitation, especially in surface soil. Besides, soil clay contents in temperate meadow were significantly higher than those in temperate typical steppe and temperate desert steppe.

Table 1

Plant $\mathrm{C}$ and $\mathrm{N}$ contents and their isotope composition in different grasslands.

\begin{tabular}{|c|c|c|c|c|c|}
\hline \multirow[t]{2}{*}{ Grassland type } & C content & $\mathrm{N}$ content & \multirow[t]{2}{*}{$\mathrm{C} / \mathrm{N}$ ratio } & $\delta^{13} \mathrm{C}$ & $\delta^{15} \mathrm{~N}$ \\
\hline & $\left(\mathrm{mg} \mathrm{g}^{-1}\right)$ & $\left(\mathrm{mg} \mathrm{g}^{-1}\right)$ & & (\%o) & $(\%)$ \\
\hline $\begin{array}{l}\text { TMS } \\
(n=9)\end{array}$ & $437.88 \pm 6.18^{a}$ & $11.68 \pm 0.83^{a}$ & $38.16 \pm 2.49^{a}$ & $-27.55 \pm 0.49^{a}$ & $3.81 \pm 1.32^{a}$ \\
\hline $\begin{array}{l}\text { TTS } \\
(n=56)\end{array}$ & $441.29 \pm 2.06^{\mathrm{ab}}$ & $20.88 \pm 0.84^{b}$ & $23.10 \pm 1.05^{\mathrm{b}}$ & $-26.39 \pm 0.31^{a}$ & $-0.78 \pm 0.34^{b}$ \\
\hline $\begin{array}{l}\text { TDS } \\
(n=20)\end{array}$ & $424.62 \pm 5.29^{b}$ & $24.17 \pm 2.02^{b}$ & $18.96 \pm 1.44^{\mathrm{b}}$ & $-23.52 \pm 0.96^{b}$ & $1.22 \pm 0.85^{a}$ \\
\hline
\end{tabular}

Note: TMS, Temperate meadow steppe; TTS, Temperate typical steppe; TDS, Temperate desert steppe. Different letters indicate significant difference among the three grassland types (LSD tests, $p<0.05)$.

Table 2

Soil pH, EC, clay, SOC and TN contents and their isotope composition, and C/N ratio in different grasslands.

\begin{tabular}{|c|c|c|c|c|c|c|c|c|c|}
\hline Type & $\begin{array}{l}\text { Depth } \\
(\mathrm{cm})\end{array}$ & $\begin{array}{l}\delta^{13} \mathrm{C} \\
(\% \circ)\end{array}$ & $\begin{array}{l}\delta^{15} \mathrm{~N} \\
(\% \circ)\end{array}$ & $\begin{array}{l}\text { SOC } \\
\left(\mathrm{mg} \mathrm{g}^{-1}\right)\end{array}$ & $\begin{array}{l}\mathrm{TN} \\
\left(\mathrm{mg} \mathrm{g}^{-1}\right)\end{array}$ & $\mathrm{C} / \mathrm{N}$ ratio & $\mathrm{pH}$ & $\begin{array}{l}\text { EC } \\
\text { (us/cm) }\end{array}$ & $\begin{array}{l}\text { Clay } \\
(\%)\end{array}$ \\
\hline \multirow{4}{*}{$\begin{array}{l}\text { TMS } \\
(n=9)\end{array}$} & $0-10$ & $-25.60 \pm 0.66^{\mathrm{Aa}}$ & $5.28 \pm 0.47^{\mathrm{Aa}}$ & $24.63 \pm 3.31^{\mathrm{Aa}}$ & $2.66 \pm 0.39 \mathrm{Aa}$ & $9.43 \pm 0.54^{\mathrm{Aa}}$ & $6.80 \pm 0.41^{\mathrm{Aa}}$ & $195.63 \pm 55.89$ & $13.39 \pm 1.71^{\mathrm{Aa}}$ \\
\hline & $10-20$ & $-25.63 \pm 0.56^{\mathrm{Aa}}$ & $5.94 \pm 0.45^{\mathrm{Aa}}$ & $24.35 \pm 6.77^{\text {Aab }}$ & $2.13 \pm 0.43^{\mathrm{Aab}}$ & $10.98 \pm 0.96^{\mathrm{Aa}}$ & $6.98 \pm 0.41^{\mathrm{Aa}}$ & $140.47 \pm 48.10$ & $11.22 \pm 1.39^{\mathrm{Aa}}$ \\
\hline & $20-40$ & $-25.19 \pm 0.44^{\mathrm{Aa}}$ & $6.47 \pm 0.55^{\mathrm{Aa}}$ & $11.78 \pm 1.75^{\mathrm{Abc}}$ & $1.24 \pm 0.20^{\mathrm{Abc}}$ & $9.74 \pm 0.44^{\mathrm{Aa}}$ & $7.30 \pm 0.46^{\mathrm{Aa}}$ & $146.11 \pm 55.31$ & $15.23 \pm 3.07^{\mathrm{Aa}}$ \\
\hline & $40-60$ & $-25.04 \pm 0.39^{a a}$ & $6.59 \pm 0.50^{\mathrm{Aa}}$ & $8.73 \pm 1.68^{\mathrm{Ac}}$ & $0.83 \pm 0.11^{\mathrm{Ac}}$ & $8.72 \pm 1.03^{\mathrm{Aa}}$ & $7.33 \pm 0.45^{\mathrm{Aa}}$ & $140.82 \pm 65.14$ & $15.89 \pm 3.61^{\mathrm{Aa}}$ \\
\hline \multirow{4}{*}{$\begin{array}{l}\text { TTS } \\
(n=56)\end{array}$} & $0-10$ & $-24.27 \pm 0.18^{\mathrm{Ba}}$ & $3.84 \pm 0.40^{\mathrm{Aa}}$ & $9.25 \pm 1.01^{\mathrm{Ba}}$ & $1.04 \pm 0.10^{\mathrm{Ba}}$ & $11.09 \pm 1.49 \mathrm{Aa}$ & $8.02 \pm 0.12^{\mathrm{Ba}}$ & $119.35 \pm 15.23$ & $6.01 \pm 0.64^{\mathrm{Ba}}$ \\
\hline & $10-20$ & $-23.77 \pm 0.19^{\mathrm{Bb}}$ & $5.03 \pm 0.39^{A b}$ & $7.85 \pm 0.88^{\mathrm{Bab}}$ & $0.97 \pm 0.12^{\text {Bab }}$ & $7.77 \pm 0.32^{\mathrm{Ab}}$ & $8.23 \pm 0.12^{\mathrm{Bab}}$ & $124.75 \pm 25.95$ & $4.44 \pm 0.60^{\mathrm{Ba}}$ \\
\hline & $20-40$ & $-23.85 \pm 0.16^{\text {Bab }}$ & $5.61 \pm 0.34^{\mathrm{Ab}}$ & $6.24 \pm 0.73^{\mathrm{Bbc}}$ & $0.79 \pm 0.10^{\mathrm{ABab}}$ & $7.63 \pm 0.54^{\mathrm{Ab}}$ & $8.34 \pm 0.11^{\mathrm{Bab}}$ & $105.84 \pm 8.09$ & $4.56 \pm 0.73^{\mathrm{Ba}}$ \\
\hline & $40-60$ & $-23.92 \pm 0.15^{\mathrm{Bab}}$ & $5.95 \pm 0.29^{A b}$ & $5.07 \pm 0.66^{\mathrm{Bc}}$ & $0.65 \pm 0.09^{A b}$ & $7.92 \pm 0.63^{\mathrm{Ab}}$ & $8.37 \pm 0.11^{\mathrm{Bb}}$ & $151.02 \pm 42.37$ & $4.48 \pm 0.71^{\mathrm{Ba}}$ \\
\hline \multirow{4}{*}{$\begin{array}{l}\text { TDS } \\
(n=20)\end{array}$} & $0-10$ & $-22.60 \pm 0.28^{\mathrm{Ba}}$ & $4.56 \pm 0.80^{\mathrm{Aa}}$ & $3.99 \pm 0.56^{\mathrm{Ca}}$ & $0.55 \pm 0.15^{\mathrm{Ca}}$ & $15.47 \pm 4.47^{\mathrm{Aa}}$ & $8.27 \pm 0.16^{\mathrm{Ba}}$ & $119.68 \pm 29.13$ & $5.22 \pm 1.71^{\mathrm{Ba}}$ \\
\hline & $10-20$ & $-22.45 \pm 0.31^{\mathrm{Ca}}$ & $5.68 \pm 0.79 \mathrm{Aa}$ & $3.66 \pm 0.46^{\mathrm{Cab}}$ & $0.62 \pm 0.09^{\mathrm{Ba}}$ & $8.95 \pm 2.17^{\mathrm{Aab}}$ & $8.18 \pm 0.16^{\mathrm{Ba}}$ & $88.51 \pm 10.36$ & $3.38 \pm 0.61^{\mathrm{Ba}}$ \\
\hline & $20-40$ & $-22.15 \pm 0.31^{\mathrm{Ca}}$ & $5.64 \pm 0.63^{\mathrm{Aa}}$ & $3.32 \pm 0.44^{\mathrm{Cab}}$ & $0.56 \pm 0.08^{\mathrm{Ba}}$ & $8.41 \pm 1.42^{\mathrm{Aab}}$ & $8.30 \pm 0.15^{\mathrm{Ba}}$ & $108.95 \pm 19.08$ & $3.81 \pm 0.70^{\mathrm{Ba}}$ \\
\hline & $40-60$ & $-22.58 \pm 0.26^{\mathrm{Ca}}$ & $5.98 \pm 0.83^{\mathrm{Aa}}$ & $2.69 \pm 0.29^{\mathrm{cb}}$ & $0.53 \pm 0.05^{\mathrm{Aa}}$ & $6.04 \pm 0.65^{\mathrm{Aab}}$ & $8.35 \pm 0.15^{\mathrm{Ba}}$ & $105.28 \pm 15.19$ & $3.67 \pm 0.63^{\mathrm{Ba}}$ \\
\hline
\end{tabular}

Note: TMS, Temperate meadow steppe; TTS, Temperate typical steppe; TDS, Temperate desert steppe. Capital letters represent significant difference in the in same layer between different grassland types based on LSD tests $(p<0.05)$. Lowercase letters represent significant difference in the same grassland type between different depths based on LSD tests $(p<0.05)$. 


\subsection{Changes of $\delta^{13} \mathrm{C}$ in different grasslands}

As shown in Table 1, mean plant $\delta^{13} \mathrm{C}$ values increased with the decrease of precipitation and increased from - $27.55 \%$ in temperate meadow steppe to $23.52 \%$ in temperate desert steppe. Different soil layers of each grasslandshowed significant difference in soil $\delta^{13} \mathrm{C}$ values (Table 2 ). Soil $\delta^{13} \mathrm{C}$ was lowest in temperate meadow steppe (from $-25.60 \%$ o to $-25.04 \%$ ) (Table 2 ). Compared to temperate meadow steppe, soil $\delta^{13} \mathrm{C}$ increased significantly by $5.2 \%$ and $11.7 \%$ in temperate typical steppe and temperate desert steppe in $0-10 \mathrm{~cm}$ layer, respectively. Climatic factors, soil physicochemical properties, and their interactions significantly affected soil $\delta^{13} \mathrm{C}$ (Figure 2). The interactions between MAT and SOC on soil $\delta^{13} \mathrm{C}$ were significant (Table 3 ).

Table 3

Summary of the results of the general linear models (GLMs) for temperate grassland of northern China, showing the effects of mean annual temperature (MAT), mean annual precipitation (MAP), soil pH, EC, SOC, TN, the soil C/N ratio, clay, plant C content and plant $\mathrm{N}$ content on plant and soil $\delta^{13} \mathrm{C}$ and $\delta^{15} \mathrm{~N}$ (at 0-10 cm depth).

\begin{tabular}{|c|c|c|c|c|c|c|c|c|c|c|c|c|}
\hline \multirow[t]{2}{*}{ Variables } & \multicolumn{3}{|c|}{ Plant $\delta^{13} \mathrm{C}$} & \multicolumn{3}{|c|}{ Soil $\delta^{13} C$} & \multicolumn{3}{|c|}{ Plant $\delta^{15} \mathrm{~N}$} & \multicolumn{3}{|c|}{ Soil $\delta^{15} N$} \\
\hline & MS & SS(\%) & $\underset{\text { value }}{p}$ & MS & SS(\%) & $p_{\text {value }}^{p}$ & MS & SS(\%) & $p_{\text {value }}^{p}$ & MS & SS(\%) & ${ }_{\text {value }}^{p}$ \\
\hline MAT & 5.13 & 1.09 & 0.42 & 48.37 & 29.29 & $<0.01$ & 76.68 & 17.33 & $<0.01$ & 84.58 & 32.72 & $<0.01$ \\
\hline MAP & 18.73 & 3.99 & 0.13 & 4.17 & 2.52 & 0.12 & 113.68 & 25.70 & $<0.01$ & 41.83 & 16.18 & $<0.01$ \\
\hline $\mathrm{pH}$ & I & I & I & 1.63 & 0.99 & 0.32 & 13.00 & 2.94 & 0.10 & 3.91 & 1.51 & 0.23 \\
\hline EC & 8.19 & 1.74 & 0.31 & l & / & / & 1.89 & 0.43 & 0.52 & 0.55 & 0.21 & 0.65 \\
\hline SOC & / & / & / & 15.88 & 9.62 & $<0.01$ & / & / & / & 8.17 & 3.16 & 0.08 \\
\hline $\mathrm{TN}$ & 6.97 & 1.49 & 0.35 & 1.68 & 1.02 & 0.32 & I & I & I & 5.89 & 2.28 & 0.14 \\
\hline $\mathrm{C} / \mathrm{N}$ ratio & 9.75 & 2.08 & 0.27 & 0.27 & 0.16 & 0.69 & 0.45 & 0.10 & 0.75 & 0.43 & 0.17 & 0.69 \\
\hline Clay & 10.99 & 2.34 & 0.24 & 0.73 & 0.44 & 0.51 & 2.47 & 0.56 & 0.46 & 0.27 & 0.10 & 0.75 \\
\hline Plant C & 10.50 & 2.24 & 0.25 & / & I & / & 19.44 & 4.40 & 0.04 & I & I & I \\
\hline Plant N & 5.41 & 1.15 & 0.41 & I & / & / & 0.90 & 0.20 & 0.66 & / & / & / \\
\hline
\end{tabular}

Note: Bold values are statistically significant $(p<0.05)$.

Abbreviations: MS: mean squares; SS: the proportion of the total variance explained by the variable.

\subsection{Changes of $\delta^{15} \mathrm{~N}$ in different grasslands}

There was significant difference in plant $\delta^{15} \mathrm{~N}$ among various grasslands in northern China. Plant $\delta^{15} \mathrm{~N}$ was highest in temperate meadow steppe (mean $3.81 \%$ o), followed by temperate desert $\left(1.22 \%\right.$ o) and temperate typical steppe $(-0.78 \%$ o) (Table 1$)$. For each grassland, soil $\delta^{15} \mathrm{~N}$ slightly increased with soil depth. In surface soil, soil $\delta^{15} \mathrm{~N}$ showed similar pattern trend with plant $\delta^{15} \mathrm{~N}$. Compared to temperate meadow steppe, soil $\delta^{15} \mathrm{~N}$ significantly decreased by $13.6 \%$ and $27.3 \%$ in temperate desert steppe and temperate typical steppe in $0-10 \mathrm{~cm}$ layer, respectively (Table 2). Climatic factors, soil texture, and their interactions significantly affected soil $\delta^{15} \mathrm{~N}$ (Figure 2). The interactions between MAT and MAP on soil $\delta^{15} \mathrm{~N}$ were significant (Table 3).

\section{Discussion}

\subsection{Factors controlling plant and soil $\delta^{13} \mathrm{C}$ in grasslands of northern China}

Previous studies have revealed strong impacts of land+use change, especially grassland degradation, on the plant and soil $\delta^{13} \mathrm{C}(\mathrm{Li}$ et al. $2021 ;$ Yang et al. 2015). However, the patterns and controls of plant and soil $\delta^{13} \mathrm{C}$ in grasslands of northern China are less well studied. In this study, the responses of plant $\delta^{13} \mathrm{C}$ values to MAP (Table 1) are consistent with the previous studies under wet climates (Bai et al. 2012; Feng et al. 2020; Peri et al. 2012). These insensitive responses could be attributed to the absence of aridity for stomatal conductance during photosynthesis (Cooper 1988; Wang et al. 2013). The plant $\delta^{13} \mathrm{C}$ could be affected by different photosynthetic pathways. $\mathrm{C}_{4}$ plants have higher water use efficiency than $\mathrm{C}_{3}$ plants and are commonly the most dominant species at sites with strong water stress (Feng et al. 2020). Plants with the $C_{3}$ photosynthetic pathway commonly have relatively lower $\delta^{13} \mathrm{C}$ values than those that use the $\mathrm{C}_{4}$ pathway (Dong et al. 2018; Li et al. 2021). Compared to temperate meadow steppe, more $\mathrm{C}_{4}$ species (e.g., Artemisia dracunculus and $A$. anethifolia) appear in the temperate typical steppe and temperate desert steppe due to the low precipitation, and its relative abundance in the community will be higher and lead to the increase of plant $\delta^{13} \mathrm{C}$ values in arid regions, especially in temperate desert steppe. Therefore, the declining trend of plant $\delta^{13} \mathrm{C}$ values at community-level in our study area mainly results from the shift in the dominant plant functional group from $\mathrm{C}_{3}$ to $\mathrm{C}_{4}$.

Plant $\delta^{13} \mathrm{C}$ values are also different among various plant species (Zheng and Shangguan 2007). Previous studies indicated that the $\delta^{13} \mathrm{C}$ values of forbs were significantly higher than those of sedges and herbages (Li et al. 2021; Zheng and Shangguan 2007). Some forbs species are competitive due to their higher water use efficiency under limited soil water availability and the decrease in stomatal conductance (Gebauer et al. 2002). Meanwhile, insufficient $\mathrm{CO}_{2}$ 
supply due to the reduction in stomatal conductance leads to higher $\delta^{13} \mathrm{C}$ values in forbs. Therefore, the decreased percentage of graminoids and sedges along with the decrease water availability from temperate meadow steppe to temperate desert steppe might be other causes for the increase plant $\delta^{13} \mathrm{C}$ values in temperate desert steppe.

In natural ecosystems, soil $\delta^{13} \mathrm{C}$ values are generally determined by plant litter $\delta^{13} \mathrm{C}$ signature, which is further supported by the positive relationship between soil and plant community level $\delta^{13} \mathrm{C}$ values in our study area (Figure 2). The variances for vegetation $\delta^{13} \mathrm{C}$ and soil $\delta^{13} \mathrm{C}$ were largely explained by the aboveground different plant community composition, suggesting that changes of the plant community composition are important to ecosystem $\mathrm{C}$ cycling among different grasslands in northern China. Besides, consistent with results of the Zoige Plateau, there was a distinct negative relationship between soil $\delta^{13} \mathrm{C}$ and MAP in our study, indicating that soil $\delta^{13} \mathrm{C}$ values in the study area are also controlled by soil moisture. At the same time, the soil $\delta^{13} \mathrm{C}$ values tend to increase in the remained SOC, because microbes prefer the ${ }^{12} \mathrm{C}$ during SOC decomposition (An and Li 2015). Thus, the accumulation of old SOC with low turnover rates can result in a relatively high soil $\delta^{13} \mathrm{C}$ value. The removal of surface soil layers due to the water and wind erosion in arid regions (e.g., temperate desert steppe) will make the remaining SOC enriched in soil $\delta^{13} \mathrm{C}$ composition.

The GLM analysis showed that MAP and SOC explained $29.29 \%$ and $9.62 \%$ of the soil $\delta^{13} \mathrm{C}$ variance, respectively (Table 3 ), indicating that MAP is an important factor controlling the soil $\delta^{13} \mathrm{C}$ variation in grasslands of northern China. The SEM analysis revealed that MAT, plant $\delta^{13} \mathrm{C}$ and the combination of SOC and STN had overall stronger effects on soil $\delta^{13} \mathrm{C}$ values than the other environmental variables (Figure 3). In addition, MAP could also indirectly affect soil $\delta^{13} \mathrm{C}$ values via influencing plant $\mathrm{N}$ contents.

\subsection{Factors controlling plant and soil $\delta^{15} \mathrm{~N}$ in grasslands of northern China}

Soil $\delta^{15} \mathrm{~N}$ composition typically ranges from $-6 \%$ o to $16 \%$, providing important information about $\mathrm{N}$ dynamics in different natural ecosystems, and (Kahmen and Buchmann 2008; Shan et al. 2019). In our study, soil $\delta^{15} \mathrm{~N}$ overall increased with depth, which was consistent with the previous studies (Dong et al. 2018). This phenomenon was mainly attributed to the biogeochemical processes such as mineralization, denitrification, plant uptake and microbial immobilization, etc., which usually preferred lighter isotope $\left({ }^{14} \mathrm{~N}\right)$ and made ${ }^{15} \mathrm{~N}$ enrichment with soil depth in $\mathrm{N}$ cycling (An and Li 2015; Li et al. 2021).

In this study, plant $\delta^{15} \mathrm{~N}$ values are negatively correlated with MAP (Figure 2), which is consistent with those in global ecosystems (Craine et al. 2010). At the same time, although the relationship between soil $\delta^{15} \mathrm{~N}$ and MAP was not significant in northern China, the soil $\delta^{15} \mathrm{~N}$ values showed a decreasing trend with increasing MAP. This trend is mainly attributed to a relatively more 'open' $\mathrm{N}$ biogeochemical cycle (that is, both $\mathrm{N}$ inputs and outputs are large relative to internal $\mathrm{N}$ cycling) in arid environments (Chen et al. 2021; Cheng et al. 2009; Yang et al. 2013). Besides, temperate desert steppe with low water availability would constrain $\mathrm{N}$ biogeochemical cycle processes such as denitrification and leaching, inhibiting the loss of $\mathrm{N}$ from the ecosystem in the form of denitrification products and leachates (Yang et al. 2013). Meanwhile, such losses in temperate meadow steppe with high water availability usually occur. Therefore, these various $\mathrm{N}$ cycle processes in different grasslands of northern China have systematic effects on soil $\delta^{15} \mathrm{~N}$ composition.

The GLM analysis showed that MAT and MAP explained $32.72 \%$ and $16.18 \%$ of the soil $\delta^{15} \mathrm{~N}$ variance, respectively (Table 3 ), indicating that climatic factors are the major factors controlling the soil $\delta^{15} \mathrm{~N}$ variation in grasslands of northern China. Indeed, the SEM analysis revealed that MAT and MAP, along with plant $\delta^{15} \mathrm{~N}$, had overall strongest effects on soil $\delta^{15} \mathrm{~N}$ values (Figure 3 ). In addition, MAT and MAP could also indirectly affect soil $\delta^{15} \mathrm{~N}$ values via its effects on plant $\delta^{15} \mathrm{~N}$ composition.

\subsection{Implications for $\mathrm{C}$ and $\mathrm{N}$ biogeochemical cycles}

Our results have three important implications for understanding the $\mathrm{C}$ and $\mathrm{N}$ biogeochemical cycles in temperate grasslands. Firstly, plant community composition influences $\mathrm{C}$ cycling via changes in the relative abundance of different functional groups (An and Li 2015; Dong et al. 2018). The appearance of more forbs and $\mathrm{C}_{4}$ species in temperate desert steppe could increase plant and soil $\delta^{13} \mathrm{C}$, plant $\mathrm{N}$ content and C/N ratio (Chen et al. 2021; Nel et al. 2018; Xia et al. 2021). All of these processes could influence on soil $\mathrm{C}$ and $\mathrm{N}$ turnover, via changing $\mathrm{N}$ mineralization rate and soil organic matter decomposition rate, Secondly, heavier $\mathrm{C}$ tends to accumulate in the remaining SOC, because microbes favor the ${ }^{12} \mathrm{C}$ during SOC decomposition (Bai et al. 2012; Cooper 1988 ; Golluscio et al. 2009). Thus, SOC with a slow turnover rate will result in a relatively high soil $\delta^{13} \mathrm{C}$ (Bird et al. 1996). In addition, the water and wind erosion of surface soils, especially in arid regions (e.g., temperate desert steppe), will make the remaining SOC enriched in soil $\delta^{13} \mathrm{C}$ (Chen et al. 2021; Feng et al. 2020), and the soil $\delta^{13} \mathrm{C}$ in our study area is mainly controlled by MAP. Thirdly, a relatively more 'open' $\mathrm{N}$ biogeochemical cycle (that is, both $\mathrm{N}$ inputs and outputs are large relative to internal $\mathrm{N}$ cycling) in arid environments (Chen et al. 2021; Cheng et al. 2009; Yang et al. 2013), and the plant and soil $\delta^{15} \mathrm{~N}$ in grasslands of northern China were mainly controlled by MAT and MAP. Taken together, the $\mathrm{C}$ and $\mathrm{N}$ isotope patterns in our study area provide insights into the effects of plant community composition and climate on $\mathrm{C}$ and $\mathrm{N}$ biogeochemical cycles in the grasslands of northern China.

\section{Conclusions}

Grasslands in northern China play a crucial role in the terrestrial biogeochemical cycles of $\mathrm{C}$ and N. In this study, different grassland ecosystems have significant different patterns of plant and soil $\delta^{13} \mathrm{C}$ and $\delta^{15} \mathrm{~N}$ values. Plant community composition, especially the increase in percentage biomass of forbs contributes most to the change in plant and soil $\delta^{13} \mathrm{C}$ and $\delta^{15} \mathrm{~N}$ values. The $\mathrm{SOC}$ with a low turnover rate in combination with strong soil erosion by water and wind in arid regions (e.g., temperate desert steppe) could result in relatively high soil $\delta^{13} \mathrm{C}$ values. Soil stable $\delta^{15} \mathrm{~N}$ composition in our study area is mainly controlled by MAT and MAP, indicating that climatic factors (MAT and MAP) play important role in regulating the stable $\delta^{13} \mathrm{C}$ and $\delta^{15} \mathrm{~N}$ compositions. The results will provide scientific references for future research on $\mathrm{C}$ and $\mathrm{N}$ biogeochemical cycles in temperate grasslands of northern China. 


\section{Declarations}

\section{Acknowledgments}

The research was supported by the National Natural Science Foundation of China (41930862 and 42141014), State's Key Project of Research and Development Plan of China (2016YFA0601002 and 2017YFC0212703).

\section{References}

1. An H, Li G (2015) Effects of grazing on carbon and nitrogen in plants and soils in a semiarid desert grassland, China. J Arid Land 7:341-349. https://doi.org/10.1007/s40333-014-0049-x

2. Bai E, Boutton TW, Liu F, Wu XB, Hallmark CT, Archer SR (2012) Spatial variation of soil $\delta^{13} \mathrm{C}$ and its relation to carbon input and soil texture in a subtropical lowland woodland. Soil Biol Biochem 44:102-112. https://doi.org/10.1016/j.soilbio.2011.09.013

3. Bardgett RD, Bullock JM, Lavorel S, Manning P, Schaffner U, Ostle N, Chomel M, Durigan G, Fry EL, Johnson D, Lavallee JM, Le Provost G, Luo S, Png K, Sankaran M, Hou X, Zhou H, Ma L, Ren W, Li X, Ding Y, Li Y, Shi H (2021) Combatting global grassland degradation. Nat Rev Earth Environ 2:720-735. https://doi.org/10.1038/s43017-021-00207-2

4. Bird MI, Head J, Chivas AR (1996) A latitudinal gradient in carbon turnover times in forest soils. Nature 381:143-146. https://doi.org/10.1038/381143a0

5. Boeckx P, Paulino L, Oyarzún C, Cleemput OV, Godoy R (2005) Soil $\delta^{15} \mathrm{~N}$ patterns in old-growth forests of southern Chile as integrator for $\mathrm{N}$-cycling. Isot Environ Healt S 41:249-259. https://doi.org/10.1080/10256010500230171

6. Booth MS, Stark JM, Rastetter E (2005) Controls on nitrogen cycling in terrestrial ecosystems: a synthetic analysis of literature data. Ecol Monogr 75:139-157. https://doi.org/10.1890/04-0988

7. Brunn M, Spielvogel S, Sauer T, Oelmann Y (2014) Temperature and precipitation effects on $\delta^{13} \mathrm{C}$ depth profiles in SOM under temperate beech forests. Geoderma 235-236:146-153. https://doi.org/10.1016/j.geoderma.2014.07.007

8. Carvalhais N, Forkel M, Khomik M (2014) Global covariation of carbon turnover times with climate in terrestrial ecosystems. Nature 514:213-217. https://doi.org/10.1038/nature13731

9. Chen X, Zhang H, Yao X, Zeng W, Wang W (2021) Latitudinal and depth patterns of soil microbial biomass carbon, nitrogen and phosphorus in grasslands of an agro-pastoral ecotone. Land Degrad Dev 32:3833-3846. https://doi.org/10.1002/ldr.3978

10. Cheng W, Chen Q, Xu Y, Han X, Li L (2009) Climate and ecosystem ${ }^{15} \mathrm{~N}$ natural abundance along a transect of Inner Mongolian grasslands: Contrasting regional patterns and global patterns. Global Biogeochem Cycle 23. https://doi.org/10.1029/2008GB003315

11. Cooper ETA (1988) Correlations between carbon isotope ratio and microhabitat in desert plants. Oecologia 76:562-566. https://doi.org/10.1007/BF00397870

12. Craine JM, Brookshire ENJ, Cramer MD, Hasselquist NJ, Koba K, Marin-Spiotta E, Wang L (2015) Ecological interpretations of nitrogen isotope ratios of terrestrial plants and soils. Plant Soil 396:1-26. https://doi.org/10.1007/s11104-015-2542-1

13. Craine JM, Elmore AJ, Aidar MPM, Bustamante M (2010) Global patterns of foliar nitrogen isotopes and their relationships with climate, mycorrhizal fungi, foliar nutrient concentrations, and nitrogen availability. New Phytol 183:980-992. https://doi.org/10.1111/j.1469-8137.2009.02917.x

14. Craine JM, Elmore AJ, Wang L, Augusto L, Baisden WT, Brookshire E, Cramer M, Hasselquist NJ, Hobbie EA, Kahmen A (2015) Convergence of soil nitrogen isotopes across global climate gradients. Sci Rep 5:8280. https://doi.org/10.1038/srep08280

15. Dixon ER, Blackwell MSA, Dhanoa MS, Berryman Z, Martinez NDLF, Junquera D, Martinez A, Murray PJ, Kemp HF, Meier-Augenstein W (2010) Measurement at the field scale of soil $\delta^{13} \mathrm{C}$ and $\delta^{15} \mathrm{~N}$ under improved grassland. Rapid Commun Mass Sp 24:511-518. https://doi.org/10.1002/rcm.4345

16. Dong S, Li Y, Zhao Z, Li Y, Liu S, Zhou H, Dong Q, Li S, Gao X, Shen H, Xu Y, Han Y, Zhang J, Yang M (2018) Land Degradation Enriches Soil $\delta^{13}$ C in Alpine Steppe and Soil $\delta^{15} \mathrm{~N}$ in Alpine Desert by Changing Plant and Soil Features on Qinghai-Tibetan Plateau. Soil Sci Soc Am J 82:960-968.

https://doi.org/10.2136/sssaj2018.01.0017

17. Fang H, Yu G, Cheng S, Zhu T, Zheng J, Mo J, Yan J, Luo Y (2011) Nitrogen-15 signals of leaf-litter-soil continuum as a possible indicator of ecosystem nitrogen saturation by forest succession and N loads. Biogeochemistry 102:251-263. https://doi.org/10.1007/s10533-010-9438-1

18. Feng J, Yang F, Wu J, Chen Q, Cheng X (2020) Contrasting soil $\mathrm{C}$ and $\mathrm{N}$ dynamics inferred from $\delta^{13} \mathrm{C}$ and $\delta^{15} \mathrm{~N}$ values along a climatic gradient in southern China. Plant Soil 452:217-231. https://doi.org/10.1007/s11104-020-04548-7

19. Gebauer RLE, Schwinning S, Ehleringer JR (2002) Interspecific competition and resource pulse utilization in a cold desert community. Ecology 83:26022616. https://doi.org/10.1890/0012-9658(2002)083[2602:ICARPU]2.0.CO;2

20. Golluscio RA, Austin AT, Martínez GCG, Gonzalez-Polo M, Sala OE, Jackson RB (2009) Sheep Grazing Decreases Organic Carbon and Nitrogen Pools in the Patagonian Steppe: Combination of Direct and Indirect Effects. Ecosystems 12:686-697. https://doi.org/doi:10.1007/s10021-009-9252-6

21. Han G, Tang Y, Liu M, Van Zwieten L, Yang X, Yu C, Wang H, Song Z (2020) Carbon-nitrogen isotope coupling of soil organic matter in a karst region under land use change, Southwest China. Agr Ecosyst Environ 301:107027. https://doi.org/10.1016/j.agee.2020.107027

22. Kahmen A, Buchmann WN (2008) Foliar $\delta^{15} \mathrm{~N}$ values characterize soil $\mathrm{N}$ cycling and reflect nitrate or ammonium preference of plants along a temperate grassland gradient. Oecologia 156:861-870. https://doi.org/10.1007/s00442-008-1028-8 
23. Li C, Peng F, Lai C, Xue X, You Q, Chen X, Liao J, Ma S, Wang T (2021) Plant community changes determine the vegetation and soil $\delta 13 \mathrm{C}$ and $\delta 15 \mathrm{~N}$ enrichment in degraded alpine grassland. Land Degrad Dev 32:2371-2382. https://doi.org/10.1002/ldr.3912

24. Liu H, Mi Z, Lin L, Wang Y, Zhang Z, Zhang F, Wang H, Liu L, Zhu B, Cao G (2018) Shifting plant species composition in response to climate change stabilizes grassland primary production. P Natl Acad Sci USA 115:4051-4056. https://doi.org/10.1073/pnas.1700299114

25. Liu J, Isbell F, Ma Q, Chen Y, Wang D (2020) Aridity and overgrazing decrease soil carbon storage by decreasing grassland plant diversity. https://doi.org/10.22541/au.159986496.67974097. Authorea

26. Luo W, Wang X, Sardans J, Wang Z, Dijkstra F, Lü X, Peñuelas J, Han X (2018) Higher capability of C3 than C4 plants to use nitrogen inferred from nitrogen stable isotopes along an aridity gradient. Plant Soil 428:93-103. https://doi.org/10.1007/s11104-018-3661-2

27. Mcdowell NG, Allen CD, Marshall L (2010) Growth, carbon-isotope discrimination, and drought-associated mortality across a Pinus ponderosa elevational transect. Global Change Biol 16:399-415. https://doi.org/10.1111/j.1365-2486.2009.01994.x

28. Nel JA, Craine JM, Cramer MD (2018) Correspondence between $\delta^{13} \mathrm{C}$ and $\delta^{15} \mathrm{~N}$ in soils suggests coordinated fractionation processes for soil $\mathrm{C}$ and $\mathrm{N}$. Plant Soil 423:257-271. https://doi.org/10.1007/s11104-017-3500-x

29. O'Mara FP (2012) The role of grasslands in food security and climate change. Ann Bot 110:1263-1270. https://doi.org/10.1093/aob/mcs209

30. Peri PL, Ladd B, Pepper DA, Bonser SP, Laffan SW, Amelung W (2012) Carbon $\left(\delta^{13} \mathrm{C}\right)$ and nitrogen $\left(\delta^{15} \mathrm{~N}\right)$ stable isotope composition in plant and soil in Southern Patagonia's native forests. Global Change Biol 18:311-321. https://doi.org/10.1111/j.1365-2486.2011.02494.x

31. Risch AC, Zimmermann S, Ochoa-Hueso R, Schütz M, Moser B et al (2019) Soil net nitrogen mineralisation across global grasslands. Nat Commu 10:4981. https://doi.org/10.1038/s41467-019-12948-2

32. Shan Y, Huang M, Suo L, Zhao X, Wu L (2019) Composition and variation of soil $\delta^{15} \mathrm{~N}$ stable isotope in natural ecosystems. CATENA $183: 104236$. https://doi.org/10.1016/j.catena.2019.104236

33. Shen H, Zhu Y, Zhao X, Geng X, Fang J (2016) Analysis of current grassland resources in China. Chinese Sci Bull 61:139. https://doi.org/10.1360/N972015-00732

34. Wang C, Wei H, Liu D, Luo W, Hou J, Cheng W, Han X, Bai E (2017) Depth profiles of soil carbon isotopes along a semi-arid grassland transect in northern China. Plant Soil 417:43-52. https://doi.org/10.1007/s11104-017-3233-X

35. Wang S, Fan J, Song M, Yu G, Lei Z (2013) Patterns of SOC and soil ${ }^{13} \mathrm{C}$ and their relations to climatic factors and soil characteristics on the QinghaiTibetan Plateau. Plant Soil 363:243-255. https://doi.org/10.1007/s11104-012-1304-6

36. Wang X, Sistla SA, Wang X, Lu X, Han X (2016) Carbon and nitrogen contents in particle-size fractions of topsoil along a $3000 \mathrm{~km}$ aridity gradient in grasslands of northern China. Biogeosciences 13:3635-3646. https://doi.org/10.5194/bg-13-3635-2016

37. Wu J, Song M, Ma W, Zhang X, Shen Z, Tarolli P, Wurst S, Shi P, Ratzmann G, Feng Y, Li M, Wang X, Tietjen B (2019) Plant and soil's $\delta^{15} \mathrm{~N}$ are regulated by climate, soil nutrients, and species diversity in alpine grasslands on the northern Tibetan Plateau. Agr Ecosyst Environ 281:111-123. https://doi.org/10.1016/j.agee.2019.05.011

38. Wu Y, Wang B, Chen D (2018) Regional-scale patterns of $\delta^{13} \mathrm{C}$ and $\delta^{15} \mathrm{~N}$ associated with multiple ecosystem functions along an aridity gradient in grassland ecosystems. Plant Soil 432:107-118. https://doi.org/10.1007/s11104-018-3781-8

39. Xia S, Song Z, Li Q, Guo L, Yu C, Singh BP, Fu X, Chen C, Wang Y, Wang H (2021) Distribution, sources, and decomposition of soil organic matter along a salinity gradient in estuarine wetlands characterized by $\mathrm{C}: \mathrm{N}$ ratio, $\delta^{13} \mathrm{C}-\delta^{15} \mathrm{~N}$, and lignin biomarker. Global Change Biol 27:417-434. https://doi.org/10.1111/gcb.15403

40. Xu X, Liu H, Song Z, Wang W, Hu G, Qi Z (2015) Response of aboveground biomass and diversity to nitrogen addition along a degradation gradient in the Inner Mongolian steppe, China. Sci Rep 5:10284. https://doi.org/10.1038/srep10284

41. Xu X, Ouyang H, Richter A, Wanek W, Cao G, Kuzyakov Y (2011) Spatio-temporal variations determine plant-microbe competition for inorganic nitrogen in an alpine meadow. J Ecol 99:563-571. https://doi.org/10.1111/j.1365-2745.2010.01789.x

42. Yan Y, Zhou X, Jiang L, Luo Y (2017) Effects of carbon turnover time on terrestrial ecosystem carbon storage. Biogeosciences 14:5441-5454. https://doi.org/10.5194/bg-14-5441-2017

43. Yang Y, Ji C, Chen L, Ding J, Cheng X, Robinson D (2015) Edaphic rather than climatic controls over ${ }^{13} \mathrm{C}$ enrichment between soil and vegetation in alpine grasslands on the Tibetan Plateau. Funct Ecol 29:839-848. https://doi.org/10.1111/1365-2435.12393

44. Yang Y, Ji C, Robinson D, Zhu B, Fang H, Shen H, Fang J (2013) Vegetation and Soil ${ }^{15} \mathrm{~N}$ Natural Abundance in Alpine Grasslands on the Tibetan Plateau: Patterns and Implications. Ecosystems 16:1013-1024. https://doi.org/10.1007/s10021-013-9664-1

45. Yao Y, Wang X, Li Y, Wang T, Shen M, Du M, He H, Li Y, Luo W, Ma M, Ma Y, Tang Y, Wang H, Zhang X, Zhang Y, Zhao L, Zhou G, Piao S (2018) Spatiotemporal pattern of gross primary productivity and its covariation with climate in China over the last thirty years. Global Change Biol $24: 184-196$. https://doi.org/10.1111/gcb.13830

46. Zheng S, Shangguan Z (2007) Spatial patterns of foliar stable carbon isotope compositions of C3 plant species in the Loess Plateau of China. Ecolo Res 22:342-353. https://doi.org/10.1007/s11284-006-0024-x

\section{Figures}


Figure 1

Distribution of study sites in temperate grassland of northern China.

Figure 2

Correlation between $\delta^{13} \mathrm{C}$ and $\delta^{15} \mathrm{~N}$ in plant and soil (at 0-10 cm depth) and climate factors, plant and soil parameters.

$X^{2}=7.520, \mathrm{P}=0.676, \mathrm{GFI}=0.977, \mathrm{RMSEA}=0.000$

a

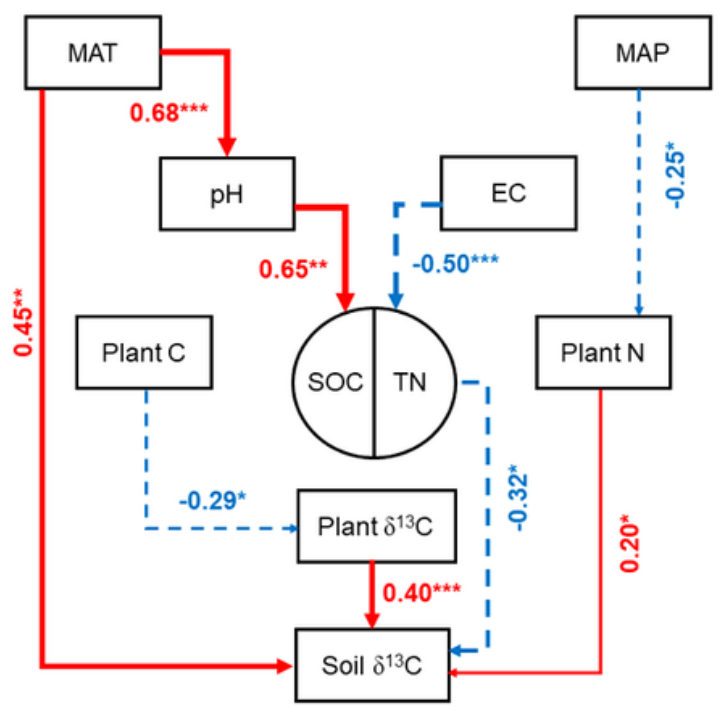

b $X^{2}=5.017, \mathrm{P}=0.756, \mathrm{GFI}=0.990, \mathrm{RMSEA}=0.000$

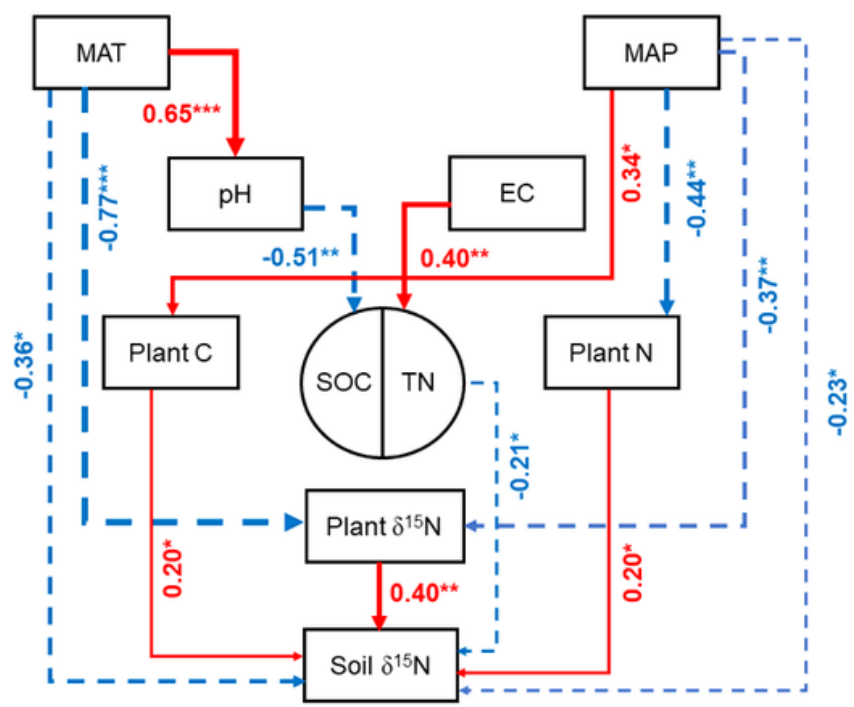

Figure 3

Structural equation model (SEM) of the effects of environmental variables on ecosystem $\delta^{13} \mathrm{C}$ and $\delta^{15} \mathrm{~N}$ values in temperate grasslands of northern China. 